\title{
QUALITY OF LIFE IN HOSPITALIZED SENIORS WITH PSYCHIATRIC DISORDERS (A CROSS-SECTIONAL STUDY FROM THE KROMERIZ DISTRICT, CZECH REPUBLIC)
}

\author{
Jan Luzny, , Katerina Ivanova ${ }^{\mathrm{b}}$ \\ ${ }^{a}$ Psychiatric Hospital Kromeriz, Czech Republic \\ ${ }^{b}$ Department of Social Medicine and Health Policy, Faculty of Medicine and Dentistry, Palacky University Olomouc \\ e-mail: luznyj@plkm.cz
}

Received: August 31, 2009; Accepted: November 20, 2009

Key words: Seniors/Quality of life/Depression/Suicidality/Loneliness

Background: The quality of life is one of tools used for a comprehensive evaluation of provided health care services. Unlike medical specialties such as oncology or transplantation medicine where maintaining or improving the quality of life has been a traditional challenge, these issues are relatively new to gerontopsychiatric practice. The article is a contribution to research into the quality of life in hospitalized seniors with psychiatric disorders.

Methods and results: We designed a cross-sectional study involving 297 patients in two study groups from two main health care institutions in the Kromeriz District, the Psychiatric Hospital Kromeriz and St. Vincent de Paul Hospital.

The WHOQOL-BREF questionnaire, MMSE, GDS, patient medical records, interviews and psychiatric assessment were used in the study.

Generally, low ability to complete the questionnaires was observed in both studied groups and a low quality of life in hospitalized seniors was revealed, together with a high prevalence of underdiagnosed depression and dementia. Poor social contacts are also common in hospitalized seniors with psychiatric disorders.

Conclusion: Continuous evaluation of the quality of life in hospitalized seniors with psychiatric disorders and attempts at its improvement should become an integral part of health care provided to older people suffering from any psychiatric condition.

\section{INTRODUCTION}

The modern concept of the quality of life has been developed for more than 90 years. Soon after World War II, mainly material and economic conditions were considered to have an influence on the perceived quality of life ${ }^{1}$. At that time, employment and good living conditions were the main prerequisite for having a good quality of life ${ }^{2}$. Later, with the development of medicine and the society, new factors influencing the quality of life emerged, such as social, political, psychological, environmental and spiritual aspects, accompanied by the concept of new lifestyle demands $^{3}$ (Table 1).

Table 1. Factors influencing the quality of life.

\begin{tabular}{|l|}
\hline \multicolumn{1}{|c|}{ Factors influencing the quality of life } \\
\hline - Health and health-related aspects \\
- Material and economic aspects \\
- Psychological aspects \\
- Spiritual aspects \\
- Social aspects and social networks \\
- Political aspects \\
- New lifestyle \\
\hline
\end{tabular}

In the 21 st century, medicine is facing new challenges, different from those in previous centuries. The prevalence of non-communicable diseases, such as obesity, hypertension, diabetes mellitus, musculoskeletal disorders and other conditions, reached the level of new pandemics replacing the earlier pandemics of infectious disease (tuberculosis, poliomyelitis etc.), having both economic and ethical impacts ${ }^{4}$. Demographic changes in the population have postponed morbidity to an older age as people live longer now. This is related to comorbidities in the elderly, growing in number and exceeding the population of children and adolescents ${ }^{5-6}$. Generally, the economic and social impacts of this demographic shift are expected to occur in most of the developed world?

The shifts in morbidity and mortality are well observed and recognized, with people dying at an older age and with more diseases. The most common causes of death are cardiovascular diseases followed by cancer ${ }^{8}$. This situation is in the Czech Republic, too ${ }^{9}$. As many of these conditions cannot be cured completely, they considerably influence the health-related quality of life the elderly patients. An approach to treatment with respect to the biopsychosocial concept of a human being may be an important way to improve the quality of life of the elderly and dying patients.

The quality of life is a complex category comprising many aspects: physical and mental condition, social networks, and environmental, educational, economic and cultural aspects of an individual ${ }^{10}$. The quality of life is highly subjective and its evaluation is problematic. Theoretically, 
the concepts of the quality of life can be divided into those of individual quality of life, those applied in health care or social care services and eclectic concepts of the quality of life, such as the WHO model ${ }^{11}$ (Table 2).

Table 2. Theoretical concepts of the quality of life.

\begin{tabular}{|l|}
\hline \multicolumn{1}{|c|}{ Theoretical concepts of the quality of life } \\
\hline - \\
- concepts of individual quality of life \\
concepts applied in health care or social care \\
- eclectic concepts of the quality of life \\
(WHO concept)
\end{tabular}

The WHO has been trying to define and evaluate the quality of life since its first definition of health in 1946. From that time on, health-related aspects of the quality of life have prevailed. For its assessment, numerous methodological tools were developed: the performance status, APACHE scoring system, quality of life indices (with the Karnofsky score being the best known), self-rated quality of life scales, quality of life questionnaires (with the EuroQol, SQUALA or WHOQOL questionnaires being the most widely used), individual interviews or focus groups $^{12-13}$ (Table 3). Any of the above-mentioned tools for measuring the quality of life can be used at different levels: an individual level - evaluating the quality of life in individuals, a group level - assessing the quality of life in groups of patients or people, and a population level measuring the quality of life in populations of patients suffering from certain diseases or undergoing some therapeutic modalities ${ }^{14}$.

Table 3. Methods for evaluating the quality of life.

\begin{tabular}{|l|}
\hline \multicolumn{1}{|c|}{ Methods forevaluating the quality of life } \\
\hline - performance status \\
- APACHE scoring system \\
- quality of life indices (the Karnofsky score) \\
- self-rated scales \\
- quality of life questionnaires \\
- individual interviews \\
- focus groups \\
\hline
\end{tabular}

When studying the quality of life, questionnaires are most frequently used. Nowadays, there are hundreds of questionnaires available that can be found in the ProQolid database of psychometric instruments ${ }^{15}$. This database comprises, among others, tools for assessing the quality of life, divided according to the research aim into generic instruments (used for the whole populations, both healthy and ill), disease-specific instruments (related to certain diseases, such as HIV or cancer) and target-population instruments (related to target populations, such as children or senior citizens) (Table 4).
Table 4. Instruments for evaluating the quality of life.

\begin{tabular}{|l|}
\hline \multicolumn{1}{|c|}{ Instruments for evaluating the quality of life } \\
\hline - generic instruments \\
- disease-specific instruments \\
- target-population instruments \\
\hline
\end{tabular}

The WHO model of the quality of life and WHO questionnaires are highly appreciated for their complex and practical approach to the quality of life. The WHO model describes the quality of life as a very heterogeneous, specific, individual and sophisticated category which can only be understood in its complexity. The WHO formed working groups for developing psychometric instruments measuring the quality of life and this painstaking research and work aimed at designing questionnaires lasted for more than 15 years before these could be used in practice. The WHO questionnaires have good psychometric characteristics and are highly recommended for research into the quality of life ${ }^{16}$.

Table 5. Well-known WHO quality of life questionnaires.

\begin{tabular}{ll|}
\hline Well-known WHO quality of life questionnaires \\
\hline - WHOQOL-100 - a generic questionnaire \\
- WHOQOL-BREF - a generic questionnaire \\
WHOQOL-Old - a target-population questionnaire \\
- WHOQOL-HIV - a disease-specific questionnaire \\
for people with HIV \\
- WHOQOL-Children - a target-population question- \\
naire for children \\
- WHOQOL-SRPB - a generic questionnaire \\
- WHOQOL-DIS - a target-population questionnaire \\
for disabled people
\end{tabular}

Traditionally, research into the quality of life has been the domain of somatic medicine ${ }^{17-18}$ (the quality of life in patients with HIV, cancer, rheumatological conditions, after transplantations or undergoing some therapeutic modalities). However, the first studies concerned with the quality of life in psychiatric patients, such as those with mood disorders or schizophrenia, have been carried out both abroad and in the Czech Republic. Research into the quality of life of the elderly patients with psychiatric morbidity in institutional care is rare abroad and has not been performed in the Czech Republic. This study is a contribution to fill this gap. The results of research carried out abroad are not very robust. This, together with different designs of the studies, makes the comparison of the quality of life in different patients difficult or impossible ${ }^{19-20}$.

\section{METHODS}

We designed a naturalistic cross-sectional study taking place in the Kromeriz District (Czech Republic) from November 2008 to May 2009. We focused on the quality 
of life in the hospitalized elderly. Two main and renowned health care institutions of the region were involved, the Psychiatric Hospital Kromeriz (gerontopsychiatric wards) and Hospital of St. Vincent de Paul in Kromeriz (geriatric wards). Whereas the geriatric wards of the Psychiatric Hospital Kromeriz provide comprehensive health care services for mentally ill seniors, the Hospital of St. Vincent de Paul is a geriatric hospital providing comprehensive health care services for physically ill elderly.

From the two facilities, two groups of elderly inpatients were recruited: a group of seniors hospitalized due to psychiatric conditions in some of the gerontopsychiatric wards of the Psychiatric Hospital Kromeriz (141 patients - 69 men, 72 women), and a group of seniors hospitalized with physical disorders in the Hospital of St. Vincent (156 patients - 54 men, 102 women).

We used the Geriatric Depression Scale (GDS), MiniMental State Examination (MMSE) and WHO Quality of Life (WHOQOL)-BREF questionnaire as psychometric instruments, together with patient medical records, interviews and psychiatric assessment.

Total scores obtained by completing the instruments were studied, together with a statistical analysis of correlation. A total GDS score above 5 was interpreted as the presence of depression, and a total MMSE score bellow 25 was considered a sign of cognitive impairment (dementia). In the WHOQOL-BREF questionnaire, the total scores range from 0 (the worst quality of life ever) to 120 (the best quality of life ever). Suicidal ideation was evaluated by interviews and comprehensive psychiatric assessment with positive or negative results, i.e. suicidal ideations are either present or absent.

The inclusion criteria were as follows: age over 65 years and giving an informed consent. The study was conducted in accordance with the principles of the Declaration of Helsinki.

Descriptive statistical analysis (the Mann-Whitney and Shapiro-Wilk tests) and inductive statistical methods (Fisher's exact test, Pearson's chi-square test) were applied using the Statistica $8 \mathrm{CZ}$ software.

\section{RESULTS}

\section{A. Characteristics of groups}

1. Hospital of St. Vincent de Paul

\begin{tabular}{|l|l|}
\hline Number of subjects & 156 patients \\
\hline Number of male patients & $54(34.6 \%)$ \\
\hline Number of female patients & 102 women $(65.4 \%)$ \\
\hline Mean age & $\begin{array}{l}76.4 \text { years } \\
\text { (standard deviation } 6.5)\end{array}$ \\
\hline $\begin{array}{l}\text { Able to complete question- } \\
\text { naires/scales }\end{array}$ & $41(26.3 \%)$ \\
\hline Total GDS score (mean) & $\begin{array}{l}6.2 \\
\text { (standard deviation 3.5) }\end{array}$ \\
\hline
\end{tabular}

\begin{tabular}{|l|l|}
\hline Total MMSE score (mean) & $\begin{array}{l}17.8 \\
\text { (standard deviation 5.0) }\end{array}$ \\
\hline $\begin{array}{l}\text { Total WHOQOL-BREF } \\
\text { score }\end{array}$ & $\begin{array}{l}88.6 \\
\text { (standard deviation 7.6) }\end{array}$ \\
\hline $\begin{array}{l}\text { Rate of underdiagnosed } \\
\text { dementia }\end{array}$ & $18.0 \%$ \\
\hline $\begin{array}{l}\text { Rate of subsyndromal or } \\
\text { moderate depression }\end{array}$ & $18.0 \%$ \\
\hline Rate of suicidal ideations & $5.8 \%$ \\
\hline
\end{tabular}

\begin{tabular}{|c|c|}
\hline \multicolumn{2}{|c|}{ 2. Psychiatric Hospital Kromeriz } \\
\hline Number of subjects & 141 patients \\
\hline Number of male patients & $69(48.9 \%)$ \\
\hline Number of female patients & $72(51.1 \%)$ \\
\hline Mean age & $\begin{array}{l}73.8 \text { years } \\
\text { (standard deviation } 6.5 \text { ) }\end{array}$ \\
\hline $\begin{array}{l}\text { Able to complete question- } \\
\text { naires/scales }\end{array}$ & $33(23.4 \%)$ \\
\hline Total GDS score (mean) & $\begin{array}{l}8.1 \\
\text { (standard deviation } 2.7 \text { ) }\end{array}$ \\
\hline Total MMSE score (mean) & $\begin{array}{l}15.7 \\
\text { (standard deviation 4.5) }\end{array}$ \\
\hline $\begin{array}{l}\text { Total WHOQOL-BREF } \\
\text { score }\end{array}$ & $\begin{array}{l}87.1 \\
\text { (standard deviation 6.9) }\end{array}$ \\
\hline $\begin{array}{l}\text { Rate of underdiagnosed } \\
\text { dementia }\end{array}$ & $\begin{array}{l}0.0 \% \text { (all cases of dementia } \\
\text { were diagnosed previously) }\end{array}$ \\
\hline $\begin{array}{l}\text { Rate of subsyndromal or } \\
\text { moderate depression }\end{array}$ & $32.0 \%$ \\
\hline Rate of suicidal ideations & $21.3 \%$ \\
\hline
\end{tabular}

Only $26.3 \%$ of subjects in the Hospital of St. Vincent de Paul and $23.4 \%$ of those from the Psychiatric Hospital Kromeriz were able to complete both the questionnaires and psychiatric assessment. The remaining patients failed due to their lack of concentration or stage of dementia.

\section{B. Results of inductive statistical methods}

The Mini-Mental State Examination (MMSE) total score was below the normal population range in both institutions, with worse MMSE score being revealed in the Psychiatric Hospital Kromeriz. A higher incidence of mild dementia was observed in the group of seniors in the Psychiatric Hospital Kromeriz; this finding is statistically significant $(p=0.04)$. Dementia was underdiagnosed in the group of patients in the Hospital of St. Vincent de Paul ( $18 \%$ of new diagnoses of dementia).

The quality of life in seniors measured by the total raw score of the WHOQOL-BREF questionnaire was low in both studied groups. Although seniors hospitalized with physical disorders in the St. Vincent de Paul Hospital (a facility with a holistic approach to therapy) 
seem to have a much higher quality of life than those in the Psychiatric Hospital Kromeriz (a conventional approach to therapy), the data analysis found no statistically significant difference between the two groups $(p=0.18)$.

The Geriatric Depression Scale (GDS) score showed the presence of subsyndromal or moderate depression in $18 \%$ of seniors in the St. Vincent de Paul Hospital, as compared with $32 \%$ of those in the Psychiatric Hospital Kromeriz. The difference between both groups was statistically significant $(\mathrm{p}=0.02)$. The incidence of depression was higher in women than in men $(\mathrm{p}=0.02)$.

Suicidal ideations were significantly more frequent in the group of seniors in the Psychiatric Hospital Kromeriz (21.3\%) than in the elderly in the St. Vincent de Paul Hospital (5.8\%). The difference between the two groups was statistically significant $(\mathrm{p}=0.03)$. This fact deserves adequate medical attention.

\section{Other facts revealed by the study}

Many seniors complained about their loneliness, suffering brought about by their disease, having little or no social contacts and actually the fact that they were hospitalized. Many of them were worried about missing their friends when they die. Feeling lonely was more frequently mentioned by women.

Interviews and psychiatric assessment revealed the patients' concerns about their future, such as where to live after being discharged from the facility, financial difficulties related to maintaining their households, worries about their health and prognosis of their diseases, fear of being incontinent and partially or completely dependent on other people's help, and fear of losing their human dignity (68\% of seniors in the St. Vincent de Paul Hospital and $51 \%$ of those in the Psychiatric Hospital Kromeriz). Comorbidity (more than one disease diagnosed in a single person) was present in $94 \%$ of patients in the St. Vincent de Paul Hospital and in $90 \%$ of seniors in the Psychiatric Hospital Kromeriz.

Surprisingly, the fear of death was less frequent than expected (12\% of the in the St. Vincent de Paul Hospital and $10 \%$ of patients in the Psychiatric Hospital Kromeriz). In both groups, the elderly were more concerned about the course of dying, especially being in pain and alone (33\% of seniors in the St. Vincent de Paul Hospital and $28 \%$ of seniors in the Psychiatric Hospital Kromeriz).

Loneliness among the elderly. During their hospitalization, about $15 \%$ of seniors in the St. Vincent de Paul Hospital and about 23\% of seniors in the Psychiatric Hospital Kromeriz were not visited by their relatives or friends.

\section{CONCLUSION}

The study is a contribution to fill the gap in the research on the quality of life in seniors hospitalized due to some psychiatric conditions. Such research is still missing in the Czech Republic.

In seniors hospitalized in the Psychiatric Hospital Kromeriz, a low quality of life was revealed, together with many cases of underdiagnosed dementia and a high prevalence of depression and poor social contacts.

As the study was limited by a relatively low number of subjects and its local character the results should be interpreted with caution.

\section{REFERENCES}

1. Hnilicová H. Kvalita života a její význam pro medicínu a zdravotnictví. In: Payne J, editor. Kvalita života a zdraví. [Quality of life and health]. (In Czech). Praha: Triton; 2005. p. 205-216.

2. Hamlin $\mathrm{Ch}$. The history and development of public health in developed countries. In: Oxford Textbook of Public health. Oxford: University Press, 2009.

3. Křivohlavý J. Psychologie zdraví. [Psychology of Health]. (In Czech). Praha: Portál; 2009.

4. Zlamal J. Ekonomie a etika. In: Ivanova K, Klos R, editors. Kapitoly z lékařské etiky. [Chapters from Medical Ethics]. (In Czech). Olomouc: VUP, 2004.

5. Topinková E. Geriatrie pro praxi [Geriatry for praxis] (In Czech). Praha: Galén, 2005.

6. Yach D, Hawkes C, Epiing-Jorda JE, Steyn K. Chronic Diseases and Risk. In: Merson HM, Black RE, Mills JA, editors. International public health. Diseases, programs, Systems, and Policies. London: Jones and Bartlett Publishers, 2006.

7. Sýkorová D. Autonomie ve stáří. Kapitoly z gerontosociologie. [Autonomy of elderly. Chapters from gerontosociology]. (In Czech). Praha: Sociologické nakladatelství, 2007.

8. Detels R. The scope and concerns of public health. In: Oxford Textbook of Public health. Oxford: University Press, 2009.

9. Janečková H, Hnilicová H. Úvod do veřejného zdravotnictví. [Introduction to Health Care Policy]. (In Czech). Praha: Galén, 2009.

10. Donabedian A. Evaluating the quality of medical care. Milbank Memorial Fund Quarterly 1966; 44: 166- 206.

11. Gladkij I. Management program zlepšování kvality ve zdravotnických institucích. In Gladkij I (Editor). Management zdravotnictví. Brno: Computer Press, 2003.

12. Dragomirecka E. WHOQOL-BREF, WHOQOL-100: World Health organization Quality of Life Assessment. Praha: Psychiatrické centrum, 2006.

13. Lužný J. Kvalita života seniorů jako jedna z výzev zdravotně sociální politiky 21. století. Thesis. [Quality of life in seniors as a challenge for health and social policy of 21 st century. Thesis]. (In Czech). Olomouc: LF UP, 2009.

14. Dragomirecka E. WHOQOL-OLD: Příručka pro uživatele české verze. [WHOQOL-OLD: Manual for users in Czech version]. (In Czech). Praha: Psychiatrické centrum, 2009.

15. ProQolid database. Internet source. Available from: www.proqolid. org (11.10.2009)

16. Chachamowich E, Trentini C, Fleck MP. Assessment of the psychometric performance of the WHOQoL-BREF instrument in a sample of Brazilian older adults. Int Psychogeriatr 2007, 19:635-46.

17. Bowling A. Enhancing later life. Aging Ment Health 2008; 12: 293-301.

18. Fry PS. Whose quality of life is it anyway? Int $\mathbf{J}$ Aging Hum Dev. 2000; 50: 361-83.

19. Gelatti $U$ et al. Health-related quality of life in older people using benzodiazepines: a cross-sectional study. Ann Ig 2006; 18: 313-26.

20. Figueiredo MDO. et al. Gender differences in the elderly. Rev Bras Enferm 2007; 60: 422-7. 